\title{
DETERMINASI KINERJA PENGELOLA KEUANGAN DI TINGKAT SMA/SMK NEGERI SE-KOTA MADIUN
}

\author{
Ririn Siswi Hani'ah \\ Magister Akuntansi \\ Fakultas Ekonomi dan Bisnis - Universitas Sebelas Maret Surakarta
}

\begin{abstract}
ABSTRAK
Tujuan dari penelitian ini adalah untuk mengetahui pengaruh pengalaman kerja, efektivitas pengelolaan dana pendidikan, pemerintahan, jenis kelamin, tingkat pendidikan, masa kerja dan posisi terhadap kinerja sekolah manajemen keuangan di SMA / SMK di Madiun. Pengumpulan data menggunakan kuesioner. Populasi dalam penelitian ini adalah bendahara BOS, DIK bendahara, panitia bendahara, kepala sekolah dan ketua komite tingkat SMK / SMA di Madiun, sebesar 55 orang. Teknik pengambilan sampel menggunakan teknik sampling jenuh. Teknik analisis menggunakan analisis regresi linier berganda, uji t dan uji F. Hasil penelitian menunjukkan: bahwa variabel pengalaman kerja memiliki pengaruh yang signifikan terhadap kinerja pengelolaan keuangan $(p=0,009)$. Efektivitas pendidikan pengelolaan dana memiliki pengaruh yang signifikan terhadap kinerja pengelolaan keuangan $(\mathrm{p}=0,032)$. Tata Kelola memiliki pengaruh yang signifikan terhadap kinerja pengelolaan keuangan $(\mathrm{p}=000)$. Karakteristik jenis kelamin memiliki pengaruh yang signifikan terhadap kinerja pengelolaan keuangan $(\mathrm{p}=0,027)$. Karakteristik tingkat pendidikan memiliki pengaruh yang signifikan terhadap kinerja pengelolaan keuangan $(\mathrm{p}=0,002)$. Karakteristik masa kerja tidak memiliki pengaruh yang signifikan terhadap kinerja pengelolaan keuangan $(\mathrm{p}=0,936)$. Dan karakteristik posisi berpengaruh signifikan terhadap kinerja pengelolaan keuangan SMA / SMK di Madiun $(\mathrm{p}=0,000)$.
\end{abstract}

Kata kunci: Pengalaman Kerja, efektivitas pengelolaan dana pendidikan, pemerintahan, jenis kelamin, tingkat pendidikan, masa kerja, posisi, kinerja pengelolaan keuangan sekolah bekerja.

\section{PENDAHULUAN}

Penggunaan dana pendidikan di sekolah harus didasarkan pada kesepakatan dan keputusan bersama antara tim manajemen sekolah, dewan guru dan komite sekolah, yang harus didaftar sebagai salah satu sumber penerimaan dalam RAPBS, disamping dana yang diperoleh dari pemda atau sumber lain yang sah. Sedikitnya ada empat hal yang harus diperhatikan dalam penggunaan dana pendidikan yaitu, efisiensi, efektifitas, transparansi, dan akuntabilitas. Pertama, efisien dalam dana pendidikan maksudnya adalah dana yang telah didapat oleh sekolah digunakan dengan sebaik-baiknya dengan memperhatikan kebutuhan-kebutuhan tiap sekolah. Artinya dana pendidikan tersebut jangan sampai salah penggunaan dan tepat sasaran sesuai dengan kebutuhan siswa atau sekolah tersebut. Kedua, artinya efektifitas sejauh mana keberhasilan yang dicapai dari hasil keputusan yang pertama. Dan efektifitas ini bisa berarti evaluasi dari program yang telah direncanakan sebelumnya. Ketiga, transparansi memiliki pengaruh yang sangat penting dalam penggunaan dana pendidikan, karena jika dari pihak sekolah kurang adanya transparansi maka dari pihak wali murid juga akan melakukan protes kepada sekolah. Ini dimaksudkan untuk mengurangi tingkat penyelewengan dari pihak sekolah. Keempat, akuntabilitas maksudnya adalah dalam pencarian dana pendidikan ini harus bisa dipertanggung jawabkan secara moral sesuai peraturan perundang-undangan yang berlaku. Jika keempat 
hal yang telah dijelaskan di atas dilakukan dengan baik, maka dana pendidikan dalam penyalurannya akan tepat sasaran (Erwantosi, 2010).

Adanya pengelolaan dana pendidikan yang dilakukan secara baik dan benar menunjukkan bahwa kinerja pengelola keuangan sekolah benar-benar menjalankan amanah sesuai dengan aturan yang berlaku. Kinerja pengelola keuangan sekolah akan dipengaruhi oleh beberapa faktor, baik internal maupun eksternal. Faktor internal yang mempengaruhi kinerja pengelola keuangan sekolah adalah terkait dengan karakteristik individu, yaitu: pengalaman kerja, gender, tingkat pendidikan, masa kerja, jabatan atau posisi individu dalam pekerjaannya. Sedangkan faktor eksternal yang mempengaruhi kinerja pengelola keuangan sekolah, yaitu: kebijakan sekolah terkait dengan efektivitas pengelolaan dana pendidikan dan kebijakan pemerintah daerah dan pusat terkait dengan pelaksanaan governance. Pembiayaan pendidikan tidak hanya menyangkut pada sumbersumber pendapatan pendidikan saja, namun lebih kepada penggunaan dana secara efektif dan efisien. Semakin efisien dana yang digunakan dalam proses pendidikan, maka berkurang pula dana yang diperlukan untuk mencapai tujuan-tujuannya. Dengan pencapaian efisiensi dana pendidikan, maka tercapai pula efektifitas kegiatan dalam pencapaian tujuan pendidikan yang diinginkan. Kedua adalah coorpoare governance, yaitu sistem yang mengatur, mengelola dan mengawasi proses pengendalian usaha untuk menaikkan nilai instansi, sekaligus sebagai bentuk perhatian pada masyarakat luas. Adanya penerapan governance yang baik akan menguntungkan instansi terkait, di mana akan mempermudah proses pengambilan keputusan, sehingga berpengaruh positif terhadap kinerja sekolah dan menghindari penyalahgunaan wewenang oleh pihak tertentu dalam pengelolaan keuangan sekolah.

\section{KAJIAN TEORI DAN HIPOTESIS Kajian Teori}

Menurut Afonso Schuknecht dan Tanzi (2003menjelaskan bahwa pengukuran kinerja sektor publik (didefinisikan sebagai hasil dari kegiatan sektor publik) dan efisiensi (didefinisikan sebagai hasilnya relatif terhadap sumber daya yang digunakan), namun, masih sangat terbatas. Lebih lanjut menurut Afonso et al., (2006), efektivitas dan efisiensi dapat diukur berdasarkan: (a) estimasi biaya; (b) estimasi output; dan (c) perbandingan antara keduanya. Menerapkan konsep ini untuk kegiatan belanja pemerintah, kita dapat mengatakan bahwa pengeluaran publik efisien ketika, mengingat jumlah yang dihabiskan sebandingkan dengan manfaat terbesar yang diperoleh.

Menurut Mihaiu Apreana dan Cristescu (2010), menjelaskan bahwa efektivitas adalah indikator yang diberikan oleh rasio hasil yang diperoleh dengan yang diprogramkan. Menurut Henri (2010), menyebutkan bahwa asumsi dasar dari efektivitas adalah lebih mudah, lebih akurat, lebih konsensual dan lebih bermanfaat untuk mengidentifikasi masalah dan kesalahan (ketidakefektifan) dibandingkan kriteria kompetensi (efektivitas). Oleh karena itu, efektivitas organisasi didefinisikan sebagai tidak adanya faktor ketidakefektifan. Menurut Homayounizadpanah dan Baqerkord (2012) menjelaskan bahwa ada hubungan positif yang kuat antara manajemen kinerja dan produktivitas. Selanjutnya, analisis juga menunjukkan bahwa manajemen kinerja dan efisiensi memiliki hubungan positif yang kuat. Dari uraian diatas dapat dikatakan bahwa efektifitas kerja berhubungan dengan hasil-hasil yang dicapai dalam arti tercapai pelaksanaan kegiatan yang menyangkut sasaran, target dan tujuan yang dikehendaki sesuai dengan rencana yang telah ditetapkan sebelumnya termasuk dalam penggunaan dana pendidikan pemerintah di SMK/SMA Negeri Kota Madiun. 
Pembiayaan pendidikan tidak hanya menyangkut pada sumber-sumber pendapatan pendidikan saja, namun lebih kepada penggunaan dana secara efektif dan efisien. Semakin efisien dana yang digunakan dalam proses pendidikan, maka berkurang pula dana yang diperlukan untuk mencapai tujuan-tujuannya. Dengan pencapaian efisiensi dana pendidikan, maka tercapai pula efektifitas kegiatan dalam pencapaian tujuan pendidikan yang diinginkan.

Arikunto (2003) menyatakan bahwa dalam pengertian umum keuangan, kegiatan pembiayaan meliputi tiga hal, yaitu: (1) penyusunan anggaran (budgeting), (2) pembukuan (accounting), dan (3) pemeriksaan (auditing). Menurut Haddad et al., (2011), menuebutkan bahwa Tata kelola perusahaan juga menyediakan struktur melalui mana tujuan perusahaan ditetapkan, dan cara-cara mencapai tujuan tersebut dan pemantauan kinerja ditentukan. Prinsip - prinsip governance merupakan titik rujukan bagi para regulator (pemerintah) dalam mengembangkan framework bagi penerapan governance.

Menurut Cushway (2002), kinerja adalah menilai bagaimana seseorang telah bekerja dibandingkan dengan target yang telah ditentukan. Rivai (2004) mengemukakan kinerja merupakan perilaku yang nyata yang ditampilkan setiap orang sebagai prestasi kerja yang dihasilkan oleh pegawai sesuai dengan perannya dalam perusahaan. Mathis dan Jackson (2001), menyatakan bahwa kinerja pada dasarnya adalah apa yang dilakukan atau tidak dilakukan pegawai. Menurut Witmore (1997), kinerja adalah pelaksanaan fungsifungsi yang dituntut dari seorang atau suatu perbuatan, suatu prestasi, suatu pameran umum keterampilan.

\section{Perumusan Hipotesis}

H1: Pengalaman kerja berpengaruh signifikan terhadap kinerja pengelola keuangan sekolah di tingkat SMA/SMK Negeri di Kota Madiun.

$\mathrm{H} 2$ : Efektifitas pengelolaan dana pendidikan berpengaruh signifikan terhadap kinerja pengelola keuangan sekolah di tingkat SMA/SMK Negeri di Kota Madiun.

H3: Governance berpengaruh signifikan terhadap kinerja pengelola keuangan sekolah di tingkat SMA/SMK Negeri di Kota Madiun.

H4: Gender berpengaruh signifikan terhadap kinerja pengelola keuangan sekolah di tingkat SMA/SMK Negeri di Kota Madiun.

H5: Tingkat pendidikan berpengaruh signifikan terhadap kinerja pengelola keuangan sekolah di tingkat SMA/SMK Negeri di Kota Madiun.

H6: Masa kerja berpengaruh signifikan terhadap kinerja pengelola keuangan sekolah di tingkat SMA/SMK Negeri di Kota Madiun.

H7: Jabatan berpengaruh signifikan terhadap kinerja pengelola keuangan sekolah di tingkat SMA/SMK Negeri di Kota Madiun.

\section{METODE PENELITIAN}

Metode penelitian ini menggunakan metode survei yaitu suatu metode pengumpulan data yang menggunakan instrumen kuesioner untuk mendapatkan tanggapan dari responden yang menjadi sampel. Populasi dalam penelitian ini adalah bendahara BOS, bendahara DIK, bendahara komite, kepala sekolah dan ketua komite tingkat SMK/SMA di Kota Madiun yang berjumlah 55 orang. Jumlah sampel penelitian ini adalah sama dengan jumah populasi, yaitu sebanyak 55 orang. Teknik pengambilan sampel menggunakan teknik sampling jenuh. 


\section{VARIABEL DAN DEFINISI OPERASIONAL}

1. Independent Variable $(\mathrm{X})$

a. Pengalaman kerja $\left(\mathrm{X}_{1}\right)$

Pengalaman kerja adalah berkaitan dengan pemahaman pengelolaan keuangan yang diperoleh dari hasil pengalaman kerja. Pengalaman kerja ini diukur berdasarkan :

1) Memiliki pengalaman untuk menyusun anggaran keuangan sekolah

2) Memiliki pengalaman kerja dalam menyusun laporan keuangan sekolah

3) Memiliki pengalaman kerja penyusun laporan keuangan di instansi lain

b. Efektifitas pengelolaan dana pendidikan $\left(\mathrm{X}_{2}\right)$

Efektivitas pengelolaan dana pendidikan adalah pencapaian hasil dari pengelolaan dana pendidikan. Egektivitas pengelolaan dana pendidikan diukur berdasarkan indikator: kelengkapan dokumen, efektivitas pembelanjaan anggaran, pelaporan biaya pendidikan

c. Governance $\left(\mathrm{X}_{3}\right)$

Governance adalah suatu sistem yang mengatur dan mengendalikan perusahaan untuk menciptakan nilai tambah (value added) untuk semua stakeholders. Indikator governance, adalah:

1) Keterbukaan (Transparency)

2) Akuntabilitas (Accountability)

3) Tanggung Jawab (Responsibility)

4) Independensi (Independency)

5) Kewajaran (Fairness)

d. Gender $\left(\mathrm{X}_{4}\right)$

Gender pada penelitian ini merupakan variabel dummy dan dikelompokkan menjadi dua kelompok, yaitu laki-laki dan perempuan.

e. Tingkat pendidikan $\left(\mathrm{X}_{5}\right)$

Tingkat pendidikan adalah jenjang pendidikan formal yang telah berhasil diselesaikan individu. Tingkat pendidikan pada penelitian ini diukur berdasarkan tingkatan pendidikan Diploma, S1 dan S2

f. Masa kerja $\left(\mathrm{X}_{6}\right)$

Masa kerja adalah masa kerja menjadi pegawai di instansi tempatnya bekerja. Masa kerja dalam penelitian ini dikelompokkan sebagai berikut : antara 11 tahun sampai 20 tahun dan di atas 20 tahun

g. Jenis jabatan $\left(\mathrm{X}_{7}\right)$

Jenis jabatan pada penelitian ini adalah berkaitan dengan posisi individu dalam pengelolaan keuangan sekolah, diantaranya: Bendahara BOS, DIK, Komite dan Supervisi

\section{Dependent variable (Y)}

Kinerja pengelola keuangan adalah suatu hasil kerja yang dicapai seseorang dalam melaksanakan tugas tugas yang dibebankan kepadanya yang didasarkan atas kecakapan, pengalaman dan kesungguhan serta waktu. Indikator kinerja pengelola keuangan, diantaranya: mutu kerja, kuantitas kerja, ketangguhan, sikap dan integritas 


\section{ANALISIS DATA DAN PEMBAHASAN}

\section{Uji Asumsi Klasik}

Uji Normalitas

Uji normalitas menunjukkan bahwa nilai Assymp Sig sebesar 0,421 lebih besar dari 0,05; dengan demikian dapat dikatakan disimpulkan bahwa data yang akan dianalisis terdistribusi normal.

\section{Uji Autokorelasi}

Uji autokorelasi menunjukkan bahwa hasil uji autokorelasi menunjukkan $\mathrm{du}<\mathrm{d}<4$-du $(1,681<1,849<2,319)$, artinya tidak ada autokorelasi positif maupun negatif.

\section{Uji Multikolinieritas}

Uji multikolinieritas menunjukkan bahwa hasil perhitungan nilai tolerance dari masing-masing variabel independent $>0,10$ yang berarti tidak ada korelasi antar variabel independent. Hasil perhitungan VIF dari masing-masing variabel independent lebih < 10. Jadi dapat disimpulkan bahwa tidak ada multikolinieritas antar variabel independent dalam model regresi.

\section{Uji Heteroskedastisitas}

Menunjukkan bahwa titik-titik menyebar secara acak serta tersebar di atas maupun di bawah angka 0 pada sumbu Y. Jadi dapat disimpulkan bahwa model regresi tidak mengandung adanya heteroskedastisitas.

\section{Hasil Analisis dan Uji Hipotesis}

Berikut adalah hasil analisis regresi berganda:

Tabel 1

Hasil Analisis Regresi Linier Berganda

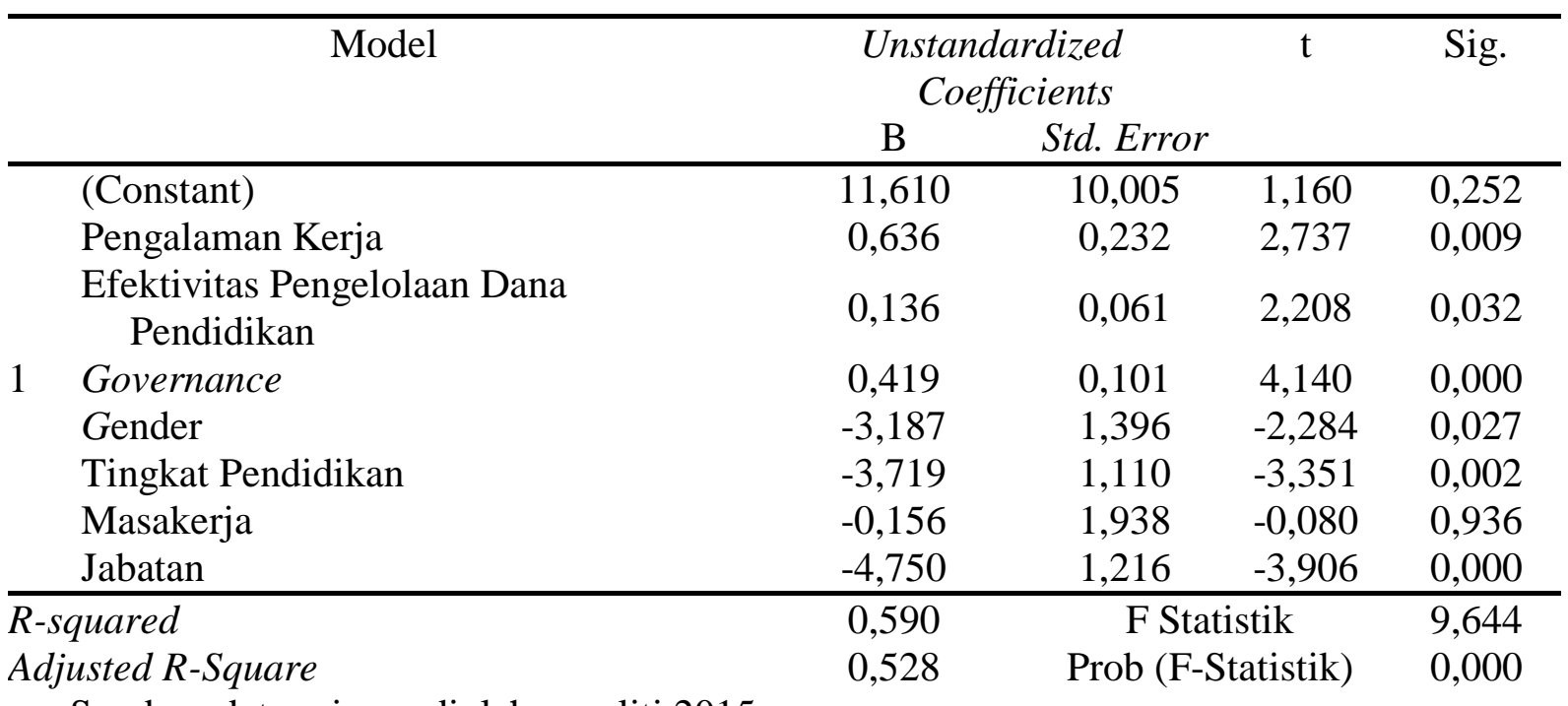

Sumber: data primer, diolah peneliti 2015

Hasil penelitian ini menunjukkan bahwa variabel pengalaman kerja memiliki pengaruh signifikan terhadap kinerja pengelola keuangan SMA/SMK di Kota Madiun. Hal ini menunjukkan bahwa semakin tinggi pengalaman kerja yang dimiliki pegawai maka kinerja pengelola keuangan sekolah juga semakin tinggi, sebaliknya semakin rendah pengalaman kerja yang dimiliki pegawai maka kinerja pengelola keuangan sekolah juga semakin rendah. Pegawai yang bertugas untuk menyusun dan pengelola dana pendidikan, rata-rata memiliki pengalaman untuk menyusun anggaran keuangan sekolah, memiliki 
pengalaman kerja dalam menyusun laporan keuangan sekolah dan memiliki pengalaman kerja penyusun laporan keuangan di instansi lain. Adanya pengalaman yang cukup baik tersebut menjadikan pegawai cakap dalam menyusun dan mengelola keuangan sesuai dengan aturan yang telah ditetapkan. Hal ini sejalan dengan teori yang dinyatakan Robbins dan Timothy (2008) bahwa pengalaman kerja didasarkan pada pengetahuan dan keterampilan yang dimiliki karyawan. Martoyo (2007) dan Alwi (2001) menyatakan bahwa pengalaman kerja didasarkan pada masa kerja atau jangka waktu karyawan dalam bekerja. Hariandja (2002) menyatakan bahwa pengalaman kerja didasarkan pada jenis pekerjaan yang pernah dikerjakan selama periode tertentu.

Variabel efektivitas pengelolaan dana pendidikan memiliki pengaruh signifikan terhadap kinerja pengelola keuangan SMA/SMK di Kota Madiun. Hal ini menunjukkan bahwa semakin tinggi efektivitas pengelolaan dana pendidikan yang ada di sekolah maka kinerja pengelola keuangan sekolah juga semakin tinggi, sebaliknya semakin rendah efektivitas pengelolaan dana pendidikan yang ada di sekolah maka kinerja pengelola keuangan sekolah juga semakin rendah. Dari analisis deskripsi hasil tanggapan responden yang berkaitan dengan efektivitas pengelolaan dana pendidikan, yang diukur berdasarkan kelengkapan dokumen, efektivitas pembelanjaan dana pendidikan dan pelaporan biaya pendidikan, menunjukkan bahwa efektivitas pengelolaan dana pendidikan yang ada di SMA/SMK Kota Madiun tergolong baik. Hasil penelitian ini menunjukkan bahwa variabel governance memiliki pengaruh signifikan terhadap kinerja pengelola keuangan SMA/SMK di Kota Madiun. Hal ini menunjukkan bahwa semakin tinggi governance yang ada di sekolah maka kinerja pengelola keuangan sekolah juga semakin tinggi, sebaliknya semakin rendah governance yang ada di sekolah maka kinerja pengelola keuangan sekolah juga semakin rendah.

Variabel gender memiliki pengaruh signifikan terhadap kinerja pengelola keuangan SMA/SMK di Kota Madiun. Hal ini menunjukkan bahwa perempuan memiliki kinerja pengelolaan keuangan sekolah yang lebih baik dibandingkan laki-laki. Pegawai perempuan yang ditugaskan untuk mengelola keuangan sekolah memiliki kinerja yang lebih baik dibandingkan dengan pegawai laki-laki, hal ini tidak terlepas dari faktor kehati-hatian yang dimiliki oleh pegawai perempuan dalam pengelolaan keuangan sekolah. Tidak dipungkiri bahwa banyak pegawai perempuan yang diberikan wewenang dalam pengelolaan keuangan dalam suatu institusi, hal ini menunjukkan bahwa perempuan dianggap lebih mampu dan lebih bisa diandalkan untuk mengelola keuangan dalam suatu instansi.

Variabel tingkat pendidikan berpengaruh signifikan terhadap kinerja pengelola keuangan SMA/SMK di Kota Madiun. Hal ini menunjukkan bahwa pegawai yang memiliki tingkat pendidikan S1 dan S2 memiliki kinerja yang lebih baik dibandingkan pegawai yang berpendidikan diploma. Hasil penelitian ini menunjukkan tingkat pendidikan yang dimiliki pegawai memiliki pengaruh terhadap kinerja dalam pengelolaan keuangan sekolah. Pendidikan adalah suatu usaha untuk mengembangkan kepribadian dan kemampuan di dalam dan di luar sekolah dan berlangsung seumur hidup. Pendidikan mempengaruhi proses belajar, makin tinggi pendidikan seeorang makin mudah orang tersebut untuk menerima informasi. Dengan pendidikan tinggi maka seseorang akan cenderung untuk mendapatkan informasi, baik dari orang lain maupun dari media massa. Semakin banyak informasi yang masuk semakin banyak pula pengetahuan yang didapat. Pengetahuan sangat erat kaitannya dengan pendidikan dimana diharapkan seseorang dengan pendidikan tinggi, maka orang tersebut akan semakin luas pula pengetahuannya.

Variabel masa kerja tidak memiliki pengaruh signifikan terhadap kinerja pengelola keuangan SMA/SMK di Kota Madiun. Pada penelitian ini masa kerja responden penelitian hampir semua responden penelitian ini memiliki masa kerja lebih dari 20 tahun yaitu 
sebanyak 53 orang atau 96,4\%. Hal ini menunjukkan bahwa masa kerja yang dimiliki responden tergolong tinggi, dan sisanya 11-20 tahun sebanyak 2 orang. Hal ini menunjukkan bahwa masa kerja yang dimiliki pegawai tergolong tinggi, sehingga antara pegawai satu dengan lain tidak ada perbedaan kinerja yang mencocok. Artinya bahwa kinerja yang dihasilkan pegawai berdasarkan masa kerja sama-sama memiliki kinerja yang baik dan antara pegawai satu dengan yang lain tidak ada perbedaan yang signifikan.

Variabel jabatan berpengaruh signifikan terhadap kinerja pengelola keuangan SMA/SMK di Kota Madiun. Hal ini menunjukkan bahwa pegawai yang menjabat sebagai supervisi memiliki kinerja yang lebih baik dibandingkan pegawai yang menjabat sebagai bendahara. Hasil penelitian ini menunjukkan bahwa supervisi yang terdiri kepala sekolah dan kepala komite memiliki kinerja yang lebih tinggi dibandingkan dengan bendahara BOS, bendahara DIK, dan bendahara komite. Kondisi menunjukkan bahwa supervisi memiliki pengetahuan yang lebih tinggi dibandingkan bawahan, sehingga supervisi akan menghasilkan kinerja yang lebih tinggi dibandingkan bawahannya.

\section{KESIMPULAN DAN SARAN} berikut:

Berdasarkan hasil analisis, maka dapat diambil beberapa kesimpulan sebagai

1. Hasil penelitian ini menunjukkan bahwa variabel pengalaman kerja, efektifitas pengelolaan dana pendidikan, governance, gender, tingka pendidikan, dan jabatan, memiliki pengaruh signifikan terhadap kinerja pengelola keuangan SMA/SMK di Kota Madiun.

2. Hasil penelitian ini menunjukkan bahwa variabel masa kerja tidak memiliki pengaruh signifikan terhadap kinerja pengelola keuangan SMA/SMK di Kota Madiun.

Berdasarkan kesimpulan, maka peneliti dapat memberikan saran untuk meningkatan kinerja pengelola keuangan sekolah sebagai berikut:

1. Untuk meningkatkan manajemen keuangan sekolah, kinerja pengelola keuangan sekolah, kepala sekolah hendaknya selalu berusaha mengevaluasi apakah pelaksanaan program kerja sekolah yang telah ditetapkan dapat berjalan sebagaimana mestinya, dan harus bersedia menerima masukan dari rekan-rekan guru, orang tua murid (komite sekolah) dan masyarakat di lingkungan sekolah. Dengan semakin banyaknya kepala sekolah dan guru-guru yang menyadari akan pentingnya pelatihan, supervisi, pembinaan, dan disiplin kerja akan berdampak positif untuk kemajuan dan mutu sekolah.

2. Bagi tenaga pengelola keuangan sekolah diharapkan agar meningkatkan kinerja dan hubungan baik dengan guru, tata usaha, komite sekolah, dan peserta didik, Dengan meningkatkannya kinerja pengelola keuangan dalam mengelola dana pendidikan, maka mutu sekolah akan semakin meningkat pula.

\section{DAFTAR PUSTAKA}

Afonso A, Schuknecht L dan Tanzi, Y. 2003. Public sector Efficiency. Working Paper Series. No. 242 / July 2003. pp. 1-38. . 2006. Public sector Efficiency. Working Paper Series. No. 581 / January 2006. pp. 1-52.

Alwi, S. 2001. Manajemen Sumber Daya Manusia Strategi Keunggulan. Kompetitif. Yogyakarta: BPFE. 
Amba, S. M. 2013. Corporate governance and firms'financial performance. Journal of Academic and Business Ethics. New York Institute of Technology, Bahrain. pp. 1-11.

Anthony, R.N. and Govindarajan, V. 2004. Management Control Systems. 11 th .ed.,. McGraw-Hill Companies,Inc., New York.

Arikunto, S. 2003. Prosedur Penelitian, Suatu Praktek. Jakarta:Bina. Aksara.

Asri, L. 2010. Budaya Organisasi. Yogyakarta: Graha Ilmu.

Azhar M. 2005. Tinjauan Atas Good Corporate Governance Di Indonesia. USU eRepository

Bafadal, I. 2004. Peningkatan Profesionalisme Guru Sekolah Dasar. Jakarta: PT. Bumi Aksara.

Basri Z dan N. D. 2008. Korelasi Antara Aspek Motivasi Dalam Penyusunan Anggaran Dengan Efektivitas Pelaksanaan Program Kegiatan Pada Pemerintahan Provinsi Nanggroe Aceh Darussalam. Jurnal Telaah \& Riset Akuntansi. Vol. 1, No. 2. Juli 2008. Hal. 123-141.

Basri, A. F. M., dan Rivai, V. 2005. Perfomance Appraisal. Jakarta:PT Raja Grafindo Persada.

Bernardin dan Russel. 2000. Human Resources Management. Mc Graw Hill, New. York.

Cascio, W. F. 1992. Managing Human Resources: Productivity, Quality of Work. Life, Profits. New York: McGraw-Hill Book Company

Cushway B. 2002. Human Resource Management. Jakarta : PT. Gramedia.

Depdiknas. 2007. Manajemen Berbasis Sekolah. Jakarta: Dirjen Manajemen Dikdasmen Direktorat Pembinaan Pendidikan Sekolah Menengah Pertama.

Dharma, A. 2001. Manajemen Supervisi. Raja Grafindo Persada, Jakarta.

Ditjen PUOD. 1993. Penelitian dan Pengkajian Satuan Biaya Sekolah. Buku Panduan: Jakarta: Ditjen PUOD Depdagri

Dori S. 2014. Analisis Kemandirian Dan Efektivitas Keuangan Daerah Pada Kabupaten Dan Kota Di Propinsi Sumatera Barat. Artikel Ilmiah. Program Studi Akuntansi Fakultas Ekonomi Universitas Negeri Padang.

DucVo dan Phan, T. 2013. Corporate Governance and Firm Performance: Empirical Evidence From Vietnam. Economic Regulation Authority, Perth, Australia. pp.119.

Erwantosi. 2010. Analisis Efektivitas, Akuntabilitas dan Transparasi Bantuan Operasional Sekolah pada Sekolah Menengah Pertama di Kota Padang. Tesis. Tidak diterbitkan. Program Pascasarjana Universitas Andalas.

Ferdi, W.P. 2013. Pembiayaan Pendidikan: Suatu Kajian Teoritis Financing Of Education:

A Theoritical Study. Jurnal Pendidikan dan Kebudayaan, Vol. 19, Nomor 4, Desember 2013. hlm. 565-578.

Forum for Corporate Governance in Indonesia (FCGI). 2002. Seri Tata Kelola Perusahaan (Corporate Governance) Jilid II; Peranan Dewan Komisaris dan Komite Audit dalam Pelaksanaan Corporate Governance. Jakarta

Ghozali, I. 2009. Aplikasi Analisis Multivariate Dengan Program SPSS, Edisi. Keempat, Penerbit Universitas Diponegoro.

Gibson, I dan Donnely. 2003. Organisasi dan Manajemen: Perilaku Struktur. Jakarta: Erlangga.

Gusnadi, dan Pratiwi B. 2008. Analisis Pengaruh Karakteristik Perusahaan dan Penerapan Good Corporate Governance Terhadap Tindakan Perataan Laba yang Dilakukan Oleh Perusahaan Yang Terdaftar di Bursa Efek Jakarta".Modus Vol.20(2):126138, Jakarta 
Haddad WMY, Saleh TA dan Fares JAS. 2011. The Effect of Corporate Governance on the Performance of Jordanian Industrial Companies: An empirical study on Amman Stock Exchange. International Journal of Humanities and Social Science. Vol. 1 No. 4; April 2011. pp. 55-69.

Hariandja, M.T.E, 2002. Manajemen Sumber Daya Manusia. Jakarta: Grasindo.

Hasibuan, M.S.P. 2005. Manajemen Sumber Daya Manusia, Edisi Revisi. Bumi Aksara, Jakarta

Henri, JF. 2010. Performance Measurement And Organizational Effectiveness: Bridging The Gap. Paper. School of Accounting Université Laval Québec City, Canada. pp.1-47.

Homayounizadpanah dan Baqerkord. 2012. Effect of Implementing Performance Management on theProductivity, Efficiency and Effectiveness of the Chabahar Municipal Employees. Research Journal of Applied Sciences, Engineering and Technology. 4(12): pp. 1767-1784.

Javed AY dan Iqbal R. 2006. Corporate Governance and Firm Performance: Evidence from Karachi Stock Exchange. The Pakistan Development Review. 45 : 4 Part II (Winter 2006) pp. 947-964.

Mangkunegara A.A.A.P. 2011. Manajemen Sumber Daya Manusia. Perusahaan. Bandung. Mardiasmo. 2009. Perpajakan. Edisi Revisi 2009. Yogyakarta. Penerbit. Andi.

Martoyo, S. 2007. Manajemen Sumber Daya Manusia. Edisi 5, Cetakan Pertama,. BPFE Yogyakarta

Mathis, R.L dan Jackson J.H. 2001. Manajemen Sumber Daya Manusia. Jilid 1, Salemba Empat, Jakarta.

Mihaiu, DM, Apreana A dan Cristescu MP. 2010. Performance Of The Public Sector. Romanian Journal of Economic Forecasting. No. 4/2010. pp. 132-147.

Mulyono, A. 2010. Pendidikan Bagi Anak Yang Berkesulitan Belajar. Jakarta: Rineka Cipta.

Nanang, F. 2003, Konsep Managemen Berbasis Sekolah (MBS) dan Dewan Sekolah. Bandung : Pustaka Bani Quraisy

Nawawi, H. 2005. Manajemen Sumber Daya Manusia Untuk Bisnis Yang Kompetitif, Cetakan Ke-4, Gajah Mada Univercity Press, Yogyakarta.

Pembukaan Undang-Undang Dasar Tahun 1945.

Peraturan Pemerintah Republik Indonesia No 48 Tahun 2008 (PP No. 48 Tahun 2008). Tentang Pendanaan Pendidikan.

Peter, M. dan John, M. 2005. Improving School Effectiveness. Terjemahan. Jakarta: Grasindo.

Raeni, R.S. 2014. Pengaruh Prinsip Keadilan, Efisiensi, Transparansi, Dan Akuntabilitas Pengelolaan Keuangan Terhadap Produktivitas SMK (Kajian Persepsi Guru SMK Se-Kabupaten Kendal). Jurusan Pendidikan Ekonomi, Fakultas Ekonomi, Universitas Negeri Semarang.

Richard, E.M. 2009. Multimedia Learning, Yogyakarta: Pustaka Pelajar.

Rivai, V. 2004. Manajemen Sumber Daya Manusia Untuk Perusahaan: Dari Teori Ke Praktik. PT. Raja Grafindo Persada, Jakarta.

Robbins, S.P dan Timothy A.J. 2008. Perilaku Organisasi Edisi ke-12,. Jakarta: Salemba

Robins, S.P. 2003. Perilaku Organisasi. Gramedia Jakarta.

Ruslan, AK, Noermijati and Susilowati C. 2013.The Influence of Organizational Commitment and Individual Competence on Teacher Performance: In the Learning Organization Perspective. (A Study on Elementary School Teachers in 
Ternate City). International Journal of Business and Behavioral Sciences. Vol. 3, No.8; Augu 2013. pp. 19-35.

Sam'ani. 2008. Pengaruh Good Corporate Governance Dan Leverage Terhadap Kinerja Keuangan Pada Perbankan yang Terdaftar di Bursa Efek Indonesia (BEI) Tahun 2004-2007. Tesis, Universitas Diponegoro, Semarang.

Schermerhorn. 2009. Management. John Wiley \& Sons.Inc, New York

Setyani S.H dan Tri S. 2012. Pengaruh Tingkat Pendidikan, Lingkungan Kerja Dan Masa Kerja Terhadap Kinerja Kepala Sekolah Smp Negeri Se Kabupaten Karanganyar Dengan Gender Sebagai Variabel Moderator. Jurnal Pendidikan. STIE “AUB" Surakarta. Hal. 1-14.

Setyowati A, Sudharto P.H dan Reni S.D. 2014. Pengaruh Budaya Kerja Dan Penerapan Good Corporate Governance Terhadap Kinerja Karyawan PT. Pos Indonesia (Persero) Kantor Pos Ungaran 50500. Jurnal Pendidikan. Jurusan Administrasi Bisnis, Fakultas Ilmu Sosial dan Ilmu Politik, Universitas Diponegoro. Hal. 1-10 Sugiyono. 2012. Metode Penelitian Kuantitatif Kualitatif dan R\&B. Bandung: Alfabeta. Sunyoto, D. 2012. Manajemen Sumber Daya Manusia. Yogyakarta: CAPS.

Sutarto. 2009. Dasar-dasar Organisasi. Cetakan ke-19. Yogyakarta: Gadjah Mada.

Syafaruddin. Al. 2001. Manajemen Sumber Daya Manusia. Strategi. Keunggulan Kompetitif. BPFE. Yogyakarta

Tabara, N dan Ungureanu M. 2012. Effects of corporate governance practices on firm performance. Journal of Accounting and Management. Vo 1 . 2, No . 3 (2012). pp. 89-95

Undang-Undang Dasar 1945, Pembukaan.

Undang-Undang Nomor 20 Tahun 2003 tentang Sistem Pendidikan Nasional

Velnampy, T. 2013. Corporate Governance and Firm Performance: A Study of Sri Lankan Manufacturing Companies. Journal of Economics and Sustainable Development. ISSN 2222-1700 (Paper) ISSN 2222-2855 (Online) Vol.4, No.3, 2013. pp. 228236.

Wahyudi, B . 2002. Manajemen Sumber Daya Manusia. Bandung: Sulita.

Werther, W.B. \& Keith D. 1996. Human Resources And Personal Management. New York.

Whitmore J. 1997. Coaching For Performance (Seni Mengarahkan Untuk Mendongkrak Kinerja). PT Gramedia Pustaka Utama. Jakarta.

Wijaya, D. 2009. Implikasi Manajemen Keuangan Sekolah Terhadap Kualitas Pendidikan. Jurnal Pendidikan Penabur. No.13/Tahun ke-8/Desember 2009.Hal 80-96. 